J. Perinat. Med. 14 (1986) 319

\title{
Herpesvirus hominis (HVH) infection in women with preterm labor
}

\author{
Marina Bujko', Vojin Sulovićé , and Rajko Dotlićc
}

${ }^{1}$ Institute of Microbiology and Immunology, and ${ }^{2}$ Department of Gynecology and Obstetrics, School of Medicine, University of Belgrade, Yugoslavia

\section{Introduction}

In a number of cases, the etiology of premature labor and birth of premature infants is still unknown. Worldwide investigations are dedicated to this problem in order to improve the prophylaxis/therapeutics, and thus reduce the incidence of premature labor and premature infant. This would contribute to the reduction of perinatal morbidity and mortality.

The etiology of preterm labor involves both medical and social factors. Acute and chronic maternal infections are considered a significant medical factor. Up to 1970 , bacteria and parasites were thought to be the main infective agents that may cause the preterm labor. Because the significance of viral infections in the perinatal period has increased, in recent years more attention has been paid to viruses, both from the aspect of premature labor and low birth weight on one hand, and from the aspect of congenital anomalies on the other (infectious embriopathies seem to be much more frequent than it is believed and investigated).

Asymptomatie maternal infections appear to be as dangerous to the fetus, as those with developed clinical picture. The influence of these infections is differently effected, depending on the gestational age in which the infectious agent acts on the fetus.

\section{Curriculum vitae}

MARINA BUjKo, M.A., was born in 1947. She studied medicine at the Belgrade University School of Medicine from which she graduated in February 1972. After finishing her term of probation she specialized in microbiology at the Institute of Microbiology and Immunology, School of Medicine, Uni-

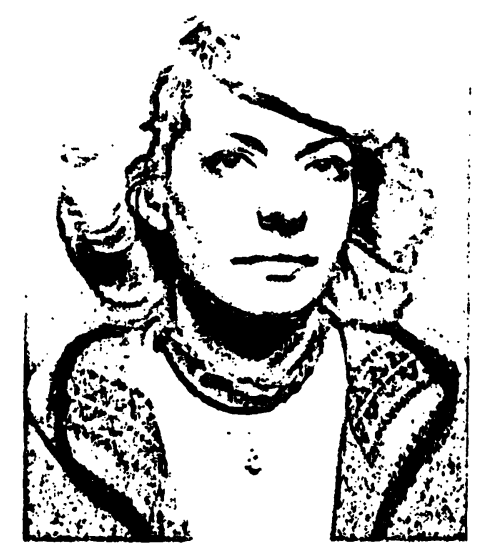
versity of Belgrade, from 1977 to 1980. She performed post graduate studies in the field of clinical immunology and virology, and obtained her MA in 1979. Since January 1977 she has been working at the Institute of Microbiology and Immunology, School of Medicine, University of Belgrade. In December 1984 she defended her thesis: "Herpes virus hominis in normal and high risk pregnancy." Her main fields of research are: Herpes simplex virus and its possible influence on pregnancy and the newborn infant.

Most viruses are embriopathogenic. This has been proved by animal experiments and retrospective clinical investigations. Presently, it is known that rubella virus, cytomegalovirus, herpesvirus hominis (herpes simplex virus) and varicella-zoster virus may act directly on the fetus and cause spontaneous abortion and preterm labor. Premature termination of pregnancy may be induced by some other viruses also, 
but their teratogenic effect has not been proved as yet.

Maternal infection by herpesvirus hominis is associated with high prenatal and postnatal risks. Primary genital $\mathrm{HVH}$ infection noted in the second half of pregnancy is considered to be the greatest risk both for mother and child. Cytologically confirmed HVH genital infection in the last trimester of pregnancy may cause premature labor, thus indicating that maternal infection represents a significant factor for premature labor [10].

\section{Material and methods}

Retrospective clinical-virologic investigations has been completed on a group of women. Twenty-one of these women have already had pre-term labor in their history. Another 20 women have served as controls. The age of examinated women was between 20 and 38 years. The reasons for previous preterm labors were unknown. There was no evidence of other gynecologic disturbances. In these women (41 altogether) examinations were aimed at the detection of the latent $\mathrm{HVH}$ type 1 and type 2 infection, and the determination of the incidence of asymptomatic cervical and vaginal HVH infection. There was no cases of primary $\mathrm{HVH}$ infection.

Latent $\mathrm{HVH}$ infection was diagnosed by the test of microneutralization, using VERO cells and the laboratory strains of HVH type 1 and type 2 (ATCC VR 539 and ATCC VR 734). The plastic plates for microneutralization containing VERO cells, virus and sera, were incubated in the atmosphere with $5 \% \mathrm{CO}_{2}$. All 41 sera were examined, and the titer of anti HVH type 1 and anti $\mathrm{HVH}$ type 2 antibodies was determined. The presence of latent $\mathrm{HVH}$ type 1 and type 2 infection, as well as dual (concomittant type 1 and 2) infection was diagnosed on the basis of these findings [8].

Asymptomatic $\mathrm{HVH}$ vaginal or cervical sheding was diagnosed by the test of indirect immunofluorescence and cytologically-Papanicolau staining (the presence of $\mathrm{HVH}$ in cervical smears was diagnosed on the basis of multinuclear cells and changes in nuclear chromatine).

The indirect immunofluorescence test was done according to the GARDNER methodology [6]. The swabs were immediately put into transport medium (Eagle Basal Medium with $10 \%$ calf serum and penicillin). In the laboratory excess fluid was compressed from the swab and all fluid was centrifugated. After centrifugation at $1600 \mathrm{rpm}$ for 10 minutes, two smears of about 10 to $15 \mathrm{~mm}$ on clean microscope slide were made from pelet, and were fixed in cold acetone and prepared for indirect immunofluorescent staining.

\section{Results}

The analysis of the results presented in table I, shows that 13 women from group $A$ and 15 from group $\mathrm{C}$ had latent $\mathrm{HVH}$ type 1 infection. Dual infection (concomittant presence of anti HVH type 1 and 2 antibodies) was found in four women from group $A$ and only 1 from group C. Four women from group $A$ and none from group $\mathrm{C}$ were found to have latent $\mathrm{HVH}$ type 2 infection. A negative serologic finding was detected in 4 women from group $\mathrm{C}$ and in none from group $\mathrm{A}$.

Statistical significance of the difference between the findings of the two groups was determined by $\mathrm{X}^{2}$-test (modified by Fisher). The obtained difference appeared to be statistically high sig-

Table I. Latent HVH infection in women who had previous preterm labor (Group A) and in control group (C).

\begin{tabular}{lrc}
\hline $\begin{array}{l}\text { The type of latent } \\
\text { HVH infection }\end{array}$ & Group A & Group C \\
\hline HVH type 1 & 13 & 15 \\
HVH type 1 & 4 & 1 \\
and 2 & & \\
HVH type 2 & 4 & 0 \\
HVH type 1 and & 0 & 4 \\
2 negative & & \\
\hline
\end{tabular}

total

21

20 
nificant $(P=0.007)$. A detailed analysis has shown that women with latent HVH type 2 infection from group A were responsible for this difference. It indicates that latent $\mathrm{HVH}$ type 2 infection was more frequent in women who have already had premature labor in their historic, than in the control group.

Vaginal asymptomatic $\mathrm{HVH}$ type 1 infection was diagnosed in one case from group $\mathrm{A}$, and in one woman from group $\mathrm{C}$ (table II). $\mathrm{HVH}$ type 2 asymptomatic infection was found in 3 women from group A and in 2 from group C. It is obvious that there is no significant difference in the presence of asymptomatic HVH type 1 and $\mathrm{HVH}$ type 2 sheding between the two groups.

Table III shows that asymptomatic $\mathrm{HVH}$ type 1 cervical infection has been detected in 2 out of 21 women from group A and in 1 out of 20 women from group $C$. The value of Fisher's test of the absolute probability when comparing these results was $P=0.39$. It means that no statistically significant difference between the groups appeared in the presence of active $\mathrm{HVH}$ type 1 cervical infection.

Table II. Asymptomatic vaginal HVH infection in women who had previous preterm labor (Group A) and in control group (C).

\begin{tabular}{llllll}
\hline Group & \multicolumn{2}{l}{ HVH type 1} & & \multicolumn{2}{l}{ HVH type 2 } \\
\cline { 2 - 3 } \cline { 5 - 6 } & positive & negative & & positive & negative \\
\hline A & 1 & 20 & 3 & 18 \\
\hline C & 1 & 19 & 2 & 18 \\
\hline
\end{tabular}

Table III. Asymptomatic cervical HVH infection in women who had previous preterm labor (Group A) and in control group (C).

\begin{tabular}{llllll}
\hline \multirow{2}{*}{ Group } & \multicolumn{2}{l}{ HVH type 1 } & & \multicolumn{2}{l}{ HVH type 2 } \\
\cline { 2 - 3 } \cline { 5 - 6 } & positive & negative & & positive & negative \\
\hline A & 2 & 19 & 4 & 17 \\
\hline C & 1 & 19 & 0 & 20 \\
\hline
\end{tabular}

Table IV. Asymptomatic cervical infection in women who had previous preterm labor (Group A) and in control group (C)-cytologic findings.

\begin{tabular}{|c|c|c|c|}
\hline \multirow[t]{2}{*}{ Group } & \multicolumn{3}{|l|}{$\mathrm{HVH}$} \\
\hline & positive & negative & vaginitis \\
\hline A & 4 & 15 & 2 \\
\hline C & 1 & 17 & 2 \\
\hline
\end{tabular}

Asymptomatic cervical $\mathrm{HVH}$ type 2 infection was found in 4 women from group $A$ and in none from group C. On the basis of the Fisher's test value $(P=0.06)$, obtained by comparison of $\mathrm{HVH}$ type 2 cervical infection of the two groups, it could be concluded that this approximates the boundery value of significance $(\mathrm{P}=\mathbf{0 . 0 5}$ represents statistically significant difference).

Cytologically evaluated HVH cervical infections in the two groups were compared (table IV). Group A showed 4 positive findings and group C only one. Vaginitis was noted in both groups, 2 cases in each, thus unabling cytologic examination. In all cases of cytologic positive results, the presence of $\mathrm{HVH}$ infection was diagnosed also by the test of immunolfuorescence.

Fisher's test revealed no statistically significant differences $(P=0.16)$.

\section{Discussion}

The presence of anti $\mathrm{HVH}$ antibodies in the serum is considered as a marker of latent $\mathrm{HVH}$ infection [3]. The possibility of latent virus to reactivate in pregnancy, and of primary $\mathrm{HVH}$ infection to occur in gravidas with negative serologic findings, is indicative of the practical value of serologic examination. It is well known that gravidas are more sensitive to infections or reactivations of latent viruses, this being explained by the depression of T-lymphocyte function [11]. 
The results of investigations done in this study within serologic examinations are suggestive of statistically significant difference between groups $\mathrm{A}$ and $\mathrm{C}$, in the presence of latent $\mathrm{HVH}$ type 2 infection. The incidence of latent $\mathrm{HVH}$ type 2 infection was higher in women with previous preterm labor; the difference was statistically significant. This finding is suggestive of a possible etiologic relationship between genital HVH type 2 infection and some cases of preterm labor.

DIAKOKU et al [4] have published a paper on the increased incidence of endometritis in gravidas who had experienced premature labor and on the role of genital infections in etiology of preterm labor. These authors have described premature labor in a pregnant woman who had vulvovaginitis caused by herpes simplex virus.

Most of authors point out that preterm labor may result from the action of different pathogenic agents, causing either subclinical or asymptomatic infections. Cord blood IgA and IgM findings may indicate a higher degree of these immunoglobulin classes in cord blood (intrauterine infection) in pregnancies with premature rupture of the membranes, than in control pregnancies [2]. The incidence of infections is higher in preterm than in term infants [9]. The presence of infectious agents in the vagina and cervix may cause ascending infection (cervical infection is more dangerous) and result in chorioamnionitis. The placenta may also be involved by the infection (placentitis). It seems likely that a local defect of the membrane, resulting from chorioamnionitis, may cause its premature rupture. Antimicrobial activity of the amniotic fluid appears to be different when causes are different, this explaining the existence of various conditions for ascending infections in the fetus and placenta [5]. Premature rupture of the membranes may result from acute intrauterine infection which intensifies uterine contractility and increases intraamniotic pressure [7].
Possible etiologic relationships between maternal genital herpes infection and preterm labor was pointed out by NAHMias et al [8], and AMSTEY and MONIF [1] discussed the likelyhood that this infection may cause premature rupture of the membranes. The results of the investigations having been carried out in this study, concerning the presence of active asymptomatic cervical infection (tables III and IV) are indicative of the significance of cervical infections in women who have already had preterm labor. The comparison of $\mathrm{HVH}$ type 2 cervical infection in the examined and control groups, have shown that the difference lies on the boundary of statistical significance. It means that further research of the subject is needed, including prospective investigations, with the aim of detecting active $\mathrm{HVH}$ infections at the time of preterm labor.

\section{Conclusion}

Ascending infection follows the choriodecidual route and may be the primary pathogenic event in a number of cases of premature rupture of the membranes and pre-term labor. Although it is not always possible to find out whether deciduo-chorioamnionitis was the cause or the result of a pre-term labor, recently accumulated data have suggested that ascending infection appears not only to be the complication secondary to the rupture of the membranes, but also the cause of pre-term labor. Virologic investigation will determine the place of viral infections in the etiology of pre-term labor. Concerning the increasing significance of genital herpetic infections in our environment, it seems reasonable to aim diagnostic efforts at the determination of both latent and active herpes virus hominis infections in order to reduce the incidence of pre-term labor and the perinatal morbidity and mortality rates by use of the appropriate preventive and therapeutic measures. 


\section{Summary}

A possible etiologic relationship between maternal asymptomatic genital $\mathrm{HVH}$ infection and pre-term labor was discussed on the base of the results of the investigation performed in this study.

Latent HVH infection was diagnosed by the test of microneutralization. Asymptomatic HVH vaginal and cervical sheding was investigated by indirect immunofluorescence and cytologically.

The incidence of latent HVH type 2 infection was higher in women with previous pre-term labor than in the control group. The obtained difference appeared to be statistically significant. The comparison of HVH type 2 asymptomatic cervical infection of the examined and the control group shows that it lies on the boundary of statistical significance. It means that further research of the subject is needed including prospective virologic investigations with the aim of detecting active $\mathrm{HVH}$ infections at the time of pre-term labor.

Concerning the increasing significance of genital HVH infections in our environment, it seems reasonable to aim diagnostic efforts at the determination of both latent and active HVH infections, in order to reduce the incidence of pre-term labor and the perinatal morbidity and mortality rates by use of the appropriate preventive and therapeutic measures.

Keywords: Asymptomatic cervicovaginal HVH sheding, cytologic examination, herpes genitalis, latent $\mathrm{HVH}$ infection, pre-term labor.

\section{Zusammenfassung}

Herpes-genitalis-Infektionen bei Frauen mit vorzeitiger Wehentätigkeit

Auf der Basis der in der vorliegenden Studie erhaltenen Ergebnisse wurde der mögliche ätiologische Zusammenhang zwischen der asymptomatischen Infektion der Mutter mit Herpes genitalis und einer vorzeitigen Wehentätigkeit diskutiert. Eine latente Infektion mit Herpes genitalis (Typ 2) wurde über einen Mikroneutralisationstest diagnostiziert. Die asymptomatische Besiedlung der Vagina und Zervix mit Herpes genitalis wurde zytologisch und über den indirekten Immunfluoreszenztest nachgewiesen.

Das Auftreten von latenten Infektionen mit Herpes Typ 2 war bei Frauen mit vorangegangener vorzeitiger Wehentätigkeit häufiger als in der Kontrollgruppe; der Un- terschied schien statistisch hochsignifikant $\mathrm{zu}$ scin. Asymptomatische Herpes-genitalis-Infektionen waren in dieser Gruppe ebenfalls häufiger als in der Kontrollgruppe, die statistische Signifikanz jedoch grenzwertig. Wir meinen, daß weitere Untersuchungen inklusive prospektiver virologischer Studien notwendig sind mit dem Ziel, eine aktive Herpes-genitalis-Infektion zum Zeitpunkt der vorzeitigen Wehentätigkeit aufzudecken.

In Hinblick auf die wachsende Bedeutung von Herpesgenitalis-Infektionen in unserem Umfeld scheint es sinnvoll, die Diagnostik sowohl der latenten wie auch der aktiven Infektion zu verbessern. Bei Einsatz adäquater präventiver und therapeutischer Maßnahmen könnte so die Häufigkeit vorzeitiger Wehen sowie die perinatale Morbidität und Mortalität gesenkt werden.

Schlüsselwörter: Asymptomatische Besiedlung von Zervix und Vagina mit Herpes Typ 2, Herpes genitalis, latente Herpes-genitalis-Infektion, vorzeitige Wehen, Zytodiagnostik.

\section{Résumé}

Infection a herpès virus hominio (H. V. H.) chez la femme présentant un travail prématuré

On discute une relation étiologique possible entre l'infection génitale maternelle asymptomatique à $\mathrm{H}$. V. H. et le travail prématuré sur la base des résultats des investigations réalisées dans cette étude.

Le diagnostic d'infection latente à $\mathrm{H}$. V. $\mathrm{H}$. a été porté par le test de micro-neutralisation. Le portage vaginal et cervical asymptomatique d'H. V. H. a été investigué par le test d'immunofluorescence indirecte et par cytologie.

L'incidence des infections latentes à $H$. V. H. de type 2 est plus élevée chez les femmes ayant antécédent du travail prématuré que dans le groupe contrôle, la différence obtenue est statistiquement hautement significative.

La comparaison des infections cervicales asymptomatiques à $H$. V. $H$. de type 2 chez les femmes examinées avec le groupe contrôlc montre des résultats à la limite de la signification statistique. Il en découle que des recherches ultérieures sur ce sujet sont nécessaires, recherches devant comprendre des explorations virologiques prospectives dans l'objectif de détecter des infections actives à $H$. V. H. au moment du travail prématuré. En ce qui concerne l'augmentation significative des infections génitales à $\mathrm{H}$. V. H. dans notre environnement, 
il semble raisonnable de centrer le diagnostic pour dépister à la fois les infections à $H$. V. H. latentes et à la fois celles qui sont actives, afin de réduire la présence du travail prématuré et le taux de morbidité et de mortalité périnatale grâce à l'utilisation de mesures préventives et thérapeutiques appropriées.

Mots-clés: Examen cytologique, herpès génital, infection à H.V.H latente, portage cervico-vảginal d'H.V.H. asymptomatique, travail prématuré.

\section{References}

[1] Amstey MS, GRG MoNIF: Genital herpes virus infection in pregnancy. Obstet Gynecol 14 (1974) 394

[2] Cederquist L, I Zervoudakis, L Ewool: The relationship between prematurely ruptured membranes and fetal immunoglobulin production. Am J Obstet Gynecol 134 (1979) 784

[3] COREY L: The diagnosis and treatment of genital herpes. JAMA 248 (1982) 1041

[4] Daikoku HN, DF Kaltremen, AV Khouzami, M SPENCE, J JOHNSON: Premature rupture of membranes and spontaneus preterm labor; maternal endometritis risks. Obstet Gynecol 59 (1982) 13

[5] Evaldson RG, A Malmborg, FC Nord: Premature rupture of the membranes and ascending infection. Br J Obstet Gynecol 39 (1982) 793

[6] GARDNER PS, J MCQUILLIN: Rapid virus DiagnosisApplication of immunofluorescence, Second Edition. Butterworth Co, London 1980

[7] LEDGER WJ: Premature rupture of the membranes and maternal-fetal infection. Clin Obstet Gynecol 22 (1979) 329
[8] Nahmias JA, EW žJosey, MZ Naib, FC Luce, A DüFEY: Antibodies to herpesvirus hominis type 1 and 2 in humans; patients with genital herpetic infections. Am J Epidemiol 91 (1970) 539

[9] Overbach A, S DANIEL, G CASEAdy: The value of umbilical cord histology in the management of potential perinatal infection. J Pediatr 76 (1970) 22

[10] St.Geme JW, JT Bailey, JT Prince, BA Burke, RA GOOD, W KRIVIT: Impaired cellular resistance to herpes simplex virus in Wiskott-Aldrich syndrome. N Engl J Med 273 (1975) 229

[11] Thong JH, RW Steele, MN Vincent, SA Hensen, JA BELLANTI: Impaired in vitro cell-mediated immunity to rubella virus during pregnancy. N Engl J Med 289 (1973) 604

Received August 20, 1984. Revised September 18, 1985. Accepted November 22, 1985.

Marina Büjko, M. A.

11000 Beograd

Tadeuša Košcuškog 78

Yugoslavia 